\title{
Analysis Certification Teachers On Teacher Professional Education In Service
}

\author{
Sri Uchtiawati \\ Dept of Mathematic Education, Faculty of Teaching Training and Education, Universitas \\ Muhammadiyah Gresik \\ sriuchtiawati@umg.ac.id
}

\begin{abstract}
ABSTRAK
The problem of this research is the need to improve the quality of Education, which in the analysis obtained by a base to enhance the quality of Education. Knowledge lies in the subsystem of teachers because basically, the teacher is learning agent. And how the efforts to upgrade the quality of Education is then, by invitation Act $s$ item of national Education and law teacher and lecturer, is it relieved I formal that teachers must have a teaching certificate, or known as a teacher's certificate (sergu). The essence of teacher certification award "teaching certificate" on teachers, which meets the standards of professional, considering teacher professionals is a prerequisite for creating quality education. The purpose of this study is shortly analysis implementation of teacher certification through Professional Teacher Education In Position (PPGJ). The research method was done by qualitative descriptive, where researcher as a key instrument, which begins from preliminary studies, followed by collecting the data by using a technique sheets observation, interviews and documentation, then triangulation, and the reduction of the data. This research was conducted at PT Muhammadiyah, which held PPG Daljab in 2018 for two periods, and in 2019 for three periods. Results from this study that professional teachers can be evidenced by the Certified Master (Gr) can be obtained one through I Professional Teacher Education in the office, with the provision begins academic selection and administration, and only after the deepening of the material model of hybrid learning on Spada and ID REN the amount of 10 credits, diving three months. Workshops and Pearteaching execution of this study in Unmuh Gresik as LPTK amount of load are 8 credits for five weeks, continue VING PPL in school partners LPTK number 6 credits for three weeks, to end activities do SMES of PPG consisting is test-related the implementation of learning carried out in partner schools and UP is a centralized online knowledge test, a maximum graduation grace period of 2 years with six times the UP retest.

Furthermore, for teachers who have passed the PPG Daljab can meng ask Teacher Certification (sergur) to receive allowances, and got the facilities that support achievement for teachers, including structural positions provided by the school. The $d$ nature of learning and mastery learning do teachers better, so Influence of Community belief against schools with teachers who already have a teacher's certificate (Gr) is large enough, can make onefactor improvement of the accreditation status of the school. Thus, schools should be able to provide support to teachers to have the opportunity to take part in the PPG in Position Program.
\end{abstract}

Keywords: teacher certification, PPG Daljab 


\section{INTRODUCTION}

The quality of Education is a system, which among other things is supported by teacher professionalism so that based on Law Number 20 of 2003 concerning the National Education System, and Law Number 14 of 2005 concerning Teachers and Lecturers, and is equipped with Government Regulation Number 19 of 2005 on National Education Standards. This grounding has professionalism teachers through Pendid fish Teacher Profession. The One implementation of the PPG is "in-service teacher professional education / PPG Daljab ". Some of the problems that become the background for teachers include the lack of several teachers as quality learning agents, especially for the frontier, outermost, and disadvantaged (3T) areas, including in distributing the needs of teachers who are often not under their needs. In the category of teacher qualifications are still going on under the standard, including the presence of teachers who are even less competent in mastering competency standards that are required, and often occurs lack of conformity between educational qualifications held by teachers based diploma owned the field of study that should include able school.The organizers of this PPG Daljab activity are carried out by the University / LPTK which has been determined by the Ministry of Education and Culture and the Directorate of Higher Education. This program is intended for teachers who have met the requirements to receive the professional allowance (certification) to increase their competence and have proof of eligibility as professional teachers, with evidence of Teacher Certification (Gr). Based on the needs of teachers who must have a teaching certificate, most of them are already predicated as teachers, so with the consideration that the school can still carry out the learning process, and can still achieve the goal that teachers who are in the school are professional, who are certified according to their achievement procedures, it is determined that the Daljab PPG program, to provide opportunities for teachers to participate.
Teachers are who have met the academic requirements to pass $\mathrm{S}$ Arjana Tier 1 or Diploma IV, competence pedagogy, professional competence, social competence and competence personality, and have evidence educator's certificate. Meanwhile, the essence of teacher certification is the process of giving educator certificates to teachers. Educator certificates are given to teachers who have met professional teacher standards(https://asepsupriadijayanaga.gurusia na.id/article/2017/7 )

Teacher Professional Education ( PPG) is held at the higher education level. It is intended for those who have passed the undergraduate education program with the aim that graduates can have a job. As proof or recognition in writing of the program 's participants or teachers who have attended the Professional Teacher Education (PPG) is a professional teaching certificate obtained at the level of Education of children of age early, primary Education and secondary Education.

Among the models or ways of organizing PPG in Indonesia is through PPG in Position (daljab) that in the implementation of this involves public universities and private, with supremacy at the University of qualified and presence LPTK and has met the requirements and support up of the Memorandum of Understanding ( MoU), system organizers and the burden of learning to follow the provisions of national Ministry of Education and Culture and the Directorate of Higher Education.

\section{LITERATURE REVIEW}

The teacher is a job professional in society, by because it was a teacher before discharge duties and responsibilities as a teacher which includes educating and teaching, guiding, directing, assessing and evaluate in the learning process, the teacher are required to have some competence and some kinds of skills that are complementary to his profession. These professionals are often associated with obtaining a diploma which is evidence to give the teacher authority and responsibility in carrying out their duties.Meaning of Teacher certification is the provision of "teaching 
certificate" on teachers, which has met professional standards, and as an attempt to realize teachers' professional ability that teachers can formulate indicators of achievement of learning, able to think HOTS critically to be possessed of learners that include attitudes, knowledge, and the skills as a whole through how to be able to be critical, creative, communicative, and collaborative which are developed, with insight into the future adaptively and flexibly.

The pattern of implementing Teacher Certification that has been carried out is by (1) Portfolio, namely through filing conducted by teachers who meet the requirements for submission, and an assessment is carried out by an assessor of the documents as submitted files. (2) Pattern PLPG (Education and Training Professional Teacher), is perfection from Porto Folio Education, Training Teacher Professional (PLPG) in the form of education and training implementation by Rayon Institution Education and Educational staff (LPTK). Learning in a pattern PLPG amount of 90 hours of learning that can take as long as ten days, and is done in the form of lectures and workshops by using active learning approach, innovative, creative, effective, and fun (PAIKEM). ( 3 ) The Pattern of Teacher Professional Education (PPG), in which Article 17 (1) of the Higher Education Law states that professional Education is higher Education after an undergraduate program that prepares students for jobs that require specialized skills requirements. And currently, it is still implemented.

The legal basis for implementation is based on Permenristekdikti Number 55 of 2017 Article 1 point 5 states, and the PPG Program is an educational program that is organized after an undergraduate or applied undergraduate program to obtain an educator certificate in early childhood education through formal Education, Primary Education, and Secondary Education. The implementation of this PPG is positioned as a study program at the LPTK and University, as an educational program that is held after the S 1 Education program and S1 / D IV Non-Education. The PPG Study Program is designed to produce professional teachers who are expected to produce graduates who are superior and ready to face the demands and dynamism in the education sector. Based on invite teachers and lecturers of Article 10, contains meaning that to be a teacher, everyone must have a teaching certificate. The Teacher Professional Education Program (PPG) is an educational program held to prepare noneducational S1 / D IV graduates who have the talent and interest in becoming a teacher to master teacher competencies according to national education standards fully ( https: //www.amongguru .com ) The definition of a teacher is teaching staff; Informal Education, within the scope of personnel management, this personnel are classified into educators and education centre, while these educators are identified as teachers, which are defined as professional educators whose main task is to educate, teach, guide, a direct, train, assess, and evaluate for students. Conventionally the teacher is as a teacher in public schools or private schools that have abilities based on formal educational background, academic qualifications S1 or D IV. In addition to meeting academic qualifications, it must have four competencies consisting of professional competence, pedagogical competence, social competence, and personality competence, and have an educator certificate. They have expressed as a teacher professional if they meet the conditions, which is evidenced by the "Certification of teachers" which is the process of certification for teachers and lecturers with the purpose of principal for deciding the feasibility of teachers as agents of learning. As a learning agent, it means that the teacher is the main actor in the learning process. Teachers who have received an educator certificate can be interpreted as being worthy of being learning agents, and secondly, they can improve the process and quality of Education.

Teaching certificate can Retrieve teachers who are qualified, through PPG, in the category of PPG In Position ( in-service training ) or from PPG Prajabatan (preservice training ). For PPG Prajab that has been implemented in Indonesia, including; (1) Boarding School PPG S1 PGSD is Education intended for PGSD S1 or D2 PGSD graduates. Education is taken for 
one year with a burden (18-20 SKS). (2) PPG S1 Basic science boarding is Education intended for Mathematics and Natural Sciences graduates. Education is taken for one year (1820 credits). (3) PPG SM3T; those are doing the Degree Program and Educate in Regions Frontier, Outermost, and Disadvantaged (SM3T). (4) Collaborative SMK PPG which is a speciality where this Education is intended for vocational teacher candidates. (5) PPG Integrated also has a special provision, which is collage education (for graduate high school from the area 3T), after passing directly from the implementation of this program they already can be certified educator is called by the term ( multi-grade ). ( 6 ) PPG Subsidized Position, with tuition fees assisted based on provisions by the Ministry of Research, Technology and Higher Education. ( 7 ) PPG Pre-Position Swadana, which all PPG implementation costs are the personal responsibility of PPG participating students. ( 8 ) PPG in Position is designated for teachers who are appointed with specific requirements, and for teachers whose status has been teaching. As for understanding how the implementation of PPG in this study is through PPG in Position. Teacher professional is an indicator of teacher quality, while to determine how the intended $\mathrm{m}$ utu education that, among others, can be measured by the quality of participant as $h$ acyl learning process, and the quality of participant. These include also determined from intelligence, interest, and effort participant that concerned.

To understand who the students are, the primary meaning is as in Law No. 20 of 2003 students are members of the community who are trying to develop their potential through the learning process that is available at certain levels, levels and types of Education, and According to Sudarwan Danim (2010: 1) Students are the leading and most important source in the formal education process. Students can learn without teachers; on the contrary, teachers cannot teach without students. Therefore, the presence of students is a necessity in the process of formal Education or institutionalized Education and demands interaction between educators and students.(Https://www.silabus.web.id/pengerti an-peserta-didik ), thus $d$ natural learning process is determined by teacher quality in terms of quality and professional teacher, the teacher's grade should perform Development Profession Sustainable (PKB), as an obligation while being a teacher, to increase professionalism, which can be determined from Education, training, self-development, and various other activities related to the profession. Implementation of teacher certification through this Daljab PPG has loaded sks on PPG according to Permenristek D ikti Number 55 of 2017 Article 20 (11) that expenses PPG Daljab learning program of at least 24 (twenty-four) credits. Under the provisions of the Permenristekdikti, which is written in Article 20 paragraph (6), that the Daljab PPG curriculum is set with a total of 24 credits, which is categorized into three forms of learning, namely first lecture-theory (deepening of academic material), second workshops, and the third practical field experience (PPL). Meanwhile, the theoretical material includes two (2) categories, namely pedagogical scholarly and academic/professional field of study. Furthermore, academic educational article with the main content of Education and the Educator Profession, in strengthening this material is directed to reinforce the basics of Education and the principles of teachers as a profession. Meanwhile, the primary material for academic/professional fields of study does not only include scientific articles, but is related to how to implement the learning, or is associated with the application of TPACK ( Technological Pedagogical and Content Knowledge ) principles. The workshops are in the form of developing/compiling learning tools, peer teaching and completing Classroom Action Research (CAR) proposals after which research is carried out by teachers based on the conditions of the participants in the school where the teacher is placed or teaching. The workshops are in the form of development/preparation of learning tools, peer teaching and Classroom Action Research (CAR) proposals. Based on these provisions.

\section{METHODE}


Methode used in research this is Descriptive qualitative, which describe teacher certification through PPG Daljab, which is mainly professional teachers are those who have a certificate as a teacher and can be reached in the form of arbitrary execution, transcripts, legislation related to the implementation of PPG in office. Later observations, for recording the results in a systematic against the subjects and among others through the Education Profession Teachers (PPG Daljab), Instruments that will be used documentation to collect data certification, which is done through PPG Daljab, which form the record of activities objects that have been observed in the implementation of program activities Professional Teacher Education In Position. Continue is done w Interview with an informant that participants PPG Daljab from the participants of phase one and two in 2018, and the participants of aspect two, four and five in 2019, with tools 1 embar structured Interview prepared to dig informant, to the key informant. Under the opinion of Estenberg in Sugiyono (2010: 233) suggests three types of interviews, namely structured, semistructured, and unstructured interviews. The research procedure consists of three main steps, namely preparation by conducting field studies, data collection procedures and research data processing procedures. Furthermore, in this research procedure, such as the opinion of Sudarwan Denim and Darwis, 2003, that the processes or stages in implementing qualitative research are flexible according to needs, in this case, data collection in the form of documents, observations and interviews begins at the implementation of PPG Daljab 2018 and 2019.

Analysis of data is done by triangulation based on information from one party and then verified by way of obtaining information from a source or the other. The results of this triangulation are followed by " data reduction ", namely making an abstract of all data collected from all field notes from observations, interviews and document review.

Reduction, data reduction is an activity to formulate concepts that accommodate from data obtained in the field, then reduction this is followed by the conclusion.

\section{RESULTS AND DISCUSSION}

The PPG program is an educational program organized for non-educational undergraduate and S-1 / D-IV graduates, while the PPG Daljab is a Professional Teacher In-Service Education (PPGJ) intended for teachers who have registered at the Ministry of Education and Culture and have been designated as good teachers at public and private schools. Implementation Daljab PPG conducted at the University appointed has the addition of the number of providers which became five -one University authorized to process organizes PPG In Position designation is based on Letter of the Director-General of Teachers and Education Personnel No. 12290 / B4.2 / GT / 2018 Regarding the Coordination of the Implementation of PPG in Position dated April 30, 2018 .

The Professional Teacher Education Program (PPG) in Position is one of the policies of the Ministry of Education and Culture to complete and complete teacher certification in office, under the contents of Law Number 14 of 2005 concerning Teachers and Lecturers. At the same time, PPG is a form of professional Education that provides services to graduates ( fresh graduates ) who wish to become licensed teachers (called Pre-service PPG) and to teachers who want to obtain professional teacher certificates (PPG in Position). Preservice PPG is taken within two semesters, with a load of 36-40 semester credit units (SKS). PPG in Position is made in one semester or equivalent to one semester with a pack of 24 SKS. PPG Daljab is intended for teachers who have taught and received recommendations from schools after meeting the requirements. After it had submitted to the Department of Education and culture for the selection of the fulfilment of the needs of the administration, and file submission teachers are on LPMP, the next new file based on the data that is compliant distributed to LPTK or University has the right to organize Daljab PPG. 
The waiting period for teachers after delivering a file as a candidate PPG Daljab takes three years there is also more than three years. This is because the number of teachers in Indonesia is enormous, and is carried out in stages. Graduation standards are set by SME PPG activities consisting of Performance Test or UKIN and Knowledge Test or UP, which are already significant provisions, to achieve the maximum percentage of graduation, it is necessary to deepen the material, especially on UP material, which material on The exam is still considered more likely to be on the equipment during undergraduate lectures, which is different from the mastery possessed when the teacher has taught, some materials have been forgotten because they are more focused on teaching material at school.

The timeframe for teachers participating in the PPG Daljab to participate in the UP is six times the activity, equivalent to two years if the teacher has not yet been declared to have passed the UP on the first exam. While the venue for the Test of Knowledge (UP) was first implemented by teacher PPG participants in places where they lecture PPG Daljab, while provisions to retake it on UP the participant can select these in question in the University / LPTK desired by registration. The decision to be accepted at the exam location following the choice still depends on the organizer, because there is a quota for the participants in the Knowledge Exam. With the program, PPG In Position can provide opportunities for teachers who have graduated to obtain allowance teacher certification or sergur, and this becomes more certain, the can improve the welfare of teachers and to improve the quality and performance of Education, for teachers who have civil servant status at least can be a way to fulfil the requirements. For civil servants, it can become material for promotion and class. The school gives priority to the addition of structural positions, such as homeroom teacher, viceprincipal, to the head of the laboratory, especially in vocational schools, and it is also possible to provide additional teaching hours.

\section{REFRENCES}

Arikunto, Suharsimi. 2006. Prosedur Penelitian Suatu Pendekatan Praktik. Jakarta: Rineka Cipta.

Agusty Ferdinand. 2002. Structural Equation Modeling dalam Penelitian Manajemen.

Buku Aplikasi Model dalam Penelitian. Dosen Fakultas Ekonomi Undip.

Andrew E. Sikula. 2011. Manajemen Sumber Daya Manusia. Bandung: Erlangga.

Borg \& Gall, 2003. Education Research. New York: Allyn and Bacon.

Bambang, P., Lina, M. 2012. Metode Penelitian Kuantitatif. Jakarta: Rajawali Pers.

Denzin, Norman K. Dan Yvonna S. Lincoln. 2009. Handbook of Qualitative Research. Yogyakarta: Pustaka Pelajar.

Emzir. 2008. Metodologi Penelitian Pendidikan Kuantitatif dan Kualitatif. Jakarta: PT Raja Grafindo Persada

Fraenkel, Jack R. Dan Norman E. Wallen. 2008. How to Design and Evaluate Research in Education. United States: Mc. Graw Hill

https://cakheppy.wordpress.com/2011/04/09/st rategi-joyfull-learning-belajarmenyenangkan

https://muhamadyogi2014.wordpress.com/201 9/01/14/jenis-jenis-pendidikan-profesiguru

Kusumah, Yaya S. 2003. Desain dan Pengembangan Bahan Ajar Matematika Interaktif Berbasiskan Teknologi Komputer. Makalah terdapat pada Seminar Proceeding National Seminar on Science and Math Education. Seminar diselenggarakan oleh FMIPA UPI Bandung bekerjasama dengan JICA.

Kunandar, 2007. Guru Profesional: Implementasi Kurikulum Tingkat 
Satuan. Pendidikan dan Sukses dalam Sertifikasi Guru, Jakarta: Raja Grafindo. Persada.

Moleong, Lexy J. 2010. Metodologi Penelitian Kualitatif. Bandung: Rosda

Punaji Setyosari, Metode Penelitian Pendidikan dan Pengembangan, Jakarta: Kencana

Rohiat. 2012. Manajemen Sekolah: teori dasar dan praktik. Bandung: PT Refika Aditama

Sukardi. 2009. Metodologi Penelitian Pendidikan Kompetensi dan Praktiknya. Jakarta: Buni Aksara

Sugiyono, 2010. Metode Penelitian Pendidikan Pendekatan Keuantitatif, Kualitatif, dan R\&D. Bandung: Alfabeta

Satori, dkk, 2010. Metodologi Penelitian Kualitatif. Bandung: Alfabeta

Sri Uchtiawati. 2017. Manajemen pendidikan dalam dimensi permasalahan. Gresik: UMG Press

Undang undang Sistem Pendidikan Nasional nomor 20 tahun 2003

Undang-undang tentang Guru dan Dosen nomor 14 tahun 